\title{
Supporting Information for \\ Real-time laboratory measurements of VOC emissions, removal rates, and byproduct formation from consumer-grade oxidation-based air cleaners
}

Qing Ye ${ }^{1}$, Jordan E. Krechmer ${ }^{2}$, Joshua D. Shutter ${ }^{3}$, Victoria P. Barber ${ }^{1}$, Yaowei Li ${ }^{4}$, Erik

Helstrom $^{1}$, Lesly J. Franco ${ }^{5}$, Joshua L. Cox ${ }^{3}$, Amy I. H. Hrdina ${ }^{1}$, Matthew B. Goss ${ }^{1}$, Nadia Tahsini $^{6}$, Manjula Canagaratna ${ }^{2}$, Frank N. Keutsch ${ }^{3,4,7}$ and Jesse H. Kroll ${ }^{1,6, *}$

1. Department of Civil and Environmental Engineering, Massachusetts Institute of Technology, Cambridge, Massachusetts 02139, United States

2. Center for Aerosol and Cloud Chemistry, Aerodyne Research Incorporated, Billerica, Massachusetts 01821, United States

3. Department of Chemistry and Chemical Biology, Harvard University, Cambridge, Massachusetts 02138, United States

4. Paulson School of Engineering and Applied Sciences, Harvard University, Cambridge, Massachusetts 02138, United States

5. Department of Earth, Atmospheric and Planetary Sciences, Massachusetts Institute of Technology, Cambridge, Massachusetts 02139, United States

6. Department of Chemical Engineering, Massachusetts Institute of Technology, Cambridge, Massachusetts 02139, United States

7. Department of Earth and Planetary Sciences, Harvard University, Cambridge, Massachusetts 02138, United States

* Corresponding author: jhkroll@mit.edu

\section{Instruments:}

Vocus proton-transfer-reaction mass spectrometer (Vocus-PTR):

A Vocus-PTR was used to measure a broad range of volatile organic compounds (VOCs) including alkenes, aromatics and relatively unoxidized organics with sub-ppt detection limits. ${ }^{1}$ VOCs in the sample gas were ionized by proton transfer reactions with the hydronium ion $\left(\mathrm{H}_{3} \mathrm{O}^{+}\right)$and are detected as VOC $\cdot \mathrm{H}^{+}$. The sensitivity of the Vocus-PTR was calibrated by sampling a flow of calibration gas that contained known concentration of compounds including acetone, $\alpha$-pinene and several other VOCs. Calibration was performed every four hours during the experiments. Here, the sensitivity of limonene was approximated by the sensitivity of $\alpha$ pinene as their proton transfer reaction rate coefficients with $\mathrm{H}_{3} \mathrm{O}^{+}$are similar. ${ }^{2}$ The concentration of toluene was estimated by knowing the amount of toluene injected into the chamber. For the rest of the compounds detected by the instrument, the concentrations were reported as acetone-equivalent concentration by applying the acetone sensitivity (7000-10000 cps ppbv ${ }^{-1}$ during the experiments).

Ammonium chemical ionization mass spectrometer $\left(\mathrm{NH}_{4}^{+}-\mathrm{CIMS}\right)$ :

Larger and more functionalized organic molecules are measured by the $\mathrm{NH}_{4}{ }^{+}$-CIMS, which is described in detail by Zaytsev et al.. ${ }^{3}$ The dominated reagent ions are $\mathrm{NH}_{4}^{+} \bullet\left(\mathrm{H}_{2} \mathrm{O}\right)_{\mathrm{n}},(\mathrm{n}=0,1$, 2 ), and organic molecules are detected as ammonium-organic clusters $\mathrm{NH}_{4}{ }^{+} \bullet(\mathrm{VOC})$ through ligand-switching reactions ${ }^{3,4}$. The instrument uses a $1 / 4$ " PFA Teflon sampling line of $1 \mathrm{~m}$ in 
length with a flow of 3.5 SLPM. The $\mathrm{NH}_{4}{ }^{+}$-CIMS instrument is designed to minimize inlet losses of sampled compounds. ${ }^{5}$ The instrument is directly calibrated for acetone, and an acetone equivalent calibration factor is applied to other species detected by $\mathrm{NH}_{4}{ }^{+}$-CIMS.

\section{Fiber laser-induced fluorescence (FILIF):}

Gas-phase HCHO was measured via laser-induced fluorescence (LIF) using the Harvard FILIF instrument. ${ }^{6-9}$ In brief, a pulsed, narrow-bandwidth UV fiber laser emitting around $353 \mathrm{~nm}$ excites a single rovibrational transition of $\mathrm{HCHO}$. The resulting fluorescence above $370 \mathrm{~nm}$ is measured by a photomultiplier tube (PMT) with a long-pass filter. The power-normalized difference in PMT counts obtained by tuning the laser between the on-peak (online) and off-peak (offline) positions is proportional to the mixing ratio of $\mathrm{HCHO}$. The proportionality constant is determined using a $\mathrm{HCHO}$ gas cylinder standard from Airgas whose mixing ratio is verified by FTIR as described in Cazorla et al.. ${ }^{8}$

One-minute averaged measurements of $\mathrm{HCHO}$ in this study have a $1 \sigma$ precision of $\pm 27 \mathrm{pptv}$ HCHO. Measurement accuracy of $10-15 \%$ are due to errors in calibration standards and the calibration system. In addition to displaying no humidity dependence, there are no known species to date that interfere with HCHO measured by LIF since an interfering species would have to exhibit a differential absorption between the online and offline positions and fluoresce above $370 \mathrm{~nm}$. However, under high concentration of ozone, it is likely that the HCHO will formed from ozone reacting with any unsaturated VOCs adsorbed on the carbon nanotube coating inside the detection cell. Therefore, the $\mathrm{HCHO}$ concentration in $\mathrm{P} 2$ represents an upper bound estimate of $\mathrm{HCHO}$ in the chamber.

\section{Total suspended organic carbon:}

Total suspended organic carbon (TOC) in the chamber is measured by use of a hightemperature catalyst to fully oxidize all organic species to $\mathrm{CO}_{2}$, followed by measurement of $\mathrm{CO}_{2}$ using a differential gas-analyzer. This approach is adapted from a similar setup used for the measurement of calibration standards for field deployed mass-spectrometers, detailed in Veres et al.. ${ }^{10}$ For the oxidation of TOC, a palladium-platinum catalyst is placed within a Supelco Carrier Gas Purifier Tube Furnace, which is heated to $500^{\circ} \mathrm{C}$. Under these conditions, organic species sampled from the chamber are converted to $\mathrm{CO}_{2}$ and $\mathrm{H}_{2} \mathrm{O}$. The output from the catalyst is sampled by the LI-7000 (Li-Cor Inc., Lincoln, Nebraska, USA), an infrared $\mathrm{CO}_{2}$ and $\mathrm{H}_{2} \mathrm{O}$ gas analyzer. The difference between the $\mathrm{CO}_{2}$ concentrations measured directly sampling from the chamber as reference and in-line with the catalyst is calculated as TOC from all organic species. To characterize the $\mathrm{CO}_{2}$ response of the LI-7000, a reference standard of $20 \mathrm{ppm}$ $\mathrm{CO}_{2}$ air, diluted with a high purity Ultra-Zero-Air standard is used. Calibrations using different volatile organic species have been used to verify the response of the TOC to a range of organic compounds.

\section{Air cleaners}

For information on the specific air cleaners used, please contact the corresponding author.

\section{Calculation of clean air delivering rate (CADR):}

The CADR calculation is similar to that used in Chen et al.. ${ }^{11}$ Assuming a perfect mixing inside the chamber, the change in VOC concentration can be written as

$$
\frac{d C}{d t}=-\left(k_{\text {total }}\right) C(t)
$$


in which

$$
k_{\text {total }}=k_{d i l}+k_{c l} .
$$

Here $k_{\text {total }}$ is the total loss rate coefficient of a given VOC measured, and is derived by fitting the decay curve to an exponential (starting at $\mathrm{t}=4-6$ mins, to give time for chamber mixing, and ending at $\mathrm{t}=60 \mathrm{~min}$ ). The clean air change rate constant by the air cleaners $\left(k_{c l}\right)$ is derived by subtracting the dilution rate constant of the chamber system ( $k_{\text {dil }}$, which is known) from $k_{\text {total }}$. Lastly, the clean air delivering rate of a given $\operatorname{VOC}\left(\mathrm{CADR}_{\mathrm{VOC}}\right)$ is calculated using

$$
C A D R_{V O C}=k_{c l} \times V
$$

where $\mathrm{V}$ is the chamber volume $\left(7.5 \mathrm{~m}^{3}\right)$.

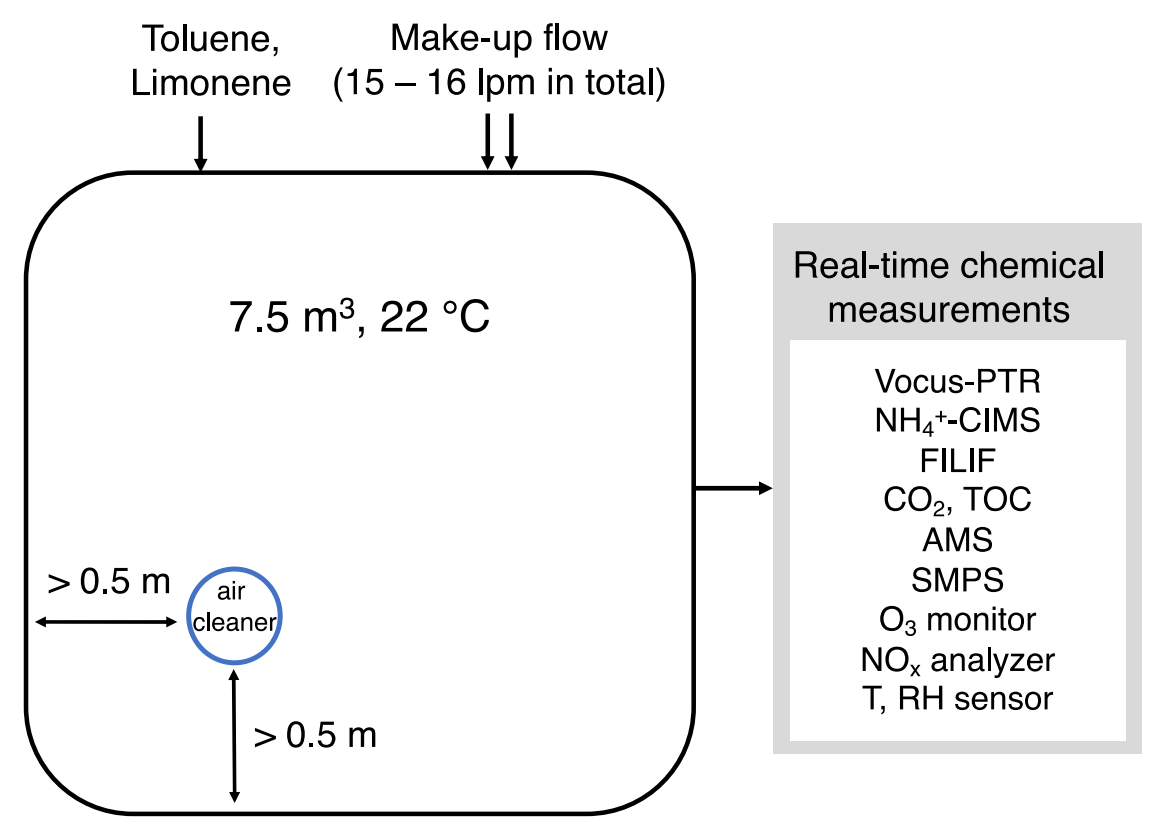

Figure S1: Schematic of chamber setup. The make-up flow includes two flow streams. To maintain the desired relative humidity (spaning from $8 \%$ to $75 \%$ in this study), one of the flow streams went through a MiliQ-water bubbler before going into the chamber. The fan in the air cleaner promoted air mixing in the experiment.

Table S1: Fan stages and approximated airflow rates of air cleaners (Q)

\begin{tabular}{|c|c|c|}
\hline Air cleaner & Fan stage & $\mathrm{Q}^{\mathrm{a}}\left(\mathrm{m}^{3} \mathrm{~s}^{-1}\right)$ \\
\hline P1 & Medium & 0.0475 \\
\hline P2 & High & 0.0014 \\
\hline P3 & Stage 2 out of 4 & 0.0619 \\
\hline P4 & Medium & 0.0259 \\
\hline
\end{tabular}

${ }^{a}$ Approximated airflow rate $\mathrm{Q}$ was determined by multiplying the speed of the flow $\left(\mathrm{m} \mathrm{s}^{-1}\right)$ by the surface area $\left(\mathrm{m}^{2}\right)$ of the fan exit. The speed of the flow was measured by an anemometer (BTMETER BT-100). 
Table S2: Instruments used in this study, the chemical species measured and the sampling frequency

\begin{tabular}{|l|l|l|}
\hline Instrument & Chemical species measured & Sampling frequency \\
\hline $\begin{array}{l}\text { Vocus proton-transfer- } \\
\text { reaction mass spectrometer } \\
\text { (Aerodyne Research Inc.) }\end{array}$ & $\begin{array}{l}\text { A broad range of VOCs } \\
\text { including alkenes, aromatic } \\
\text { hydrocarbons and some } \\
\text { oxygenated VOCs }\end{array}$ & $1 \mathrm{~s}^{-1}$ \\
\hline $\begin{array}{l}\text { Ammonium chemical } \\
\text { ionization mass spectrometer } \\
\text { (Ionicon Analytik) }\end{array}$ & $\begin{array}{l}\text { A broad range of oxygenated } \\
\text { VOCs }\end{array}$ & $1 \mathrm{~s}^{-1}$ \\
\hline $\begin{array}{l}\text { Fiber laser-induced } \\
\text { fluorescence (FILIF) }\end{array}$ & Formaldehyde & $10 \mathrm{~s}^{-1}$ \\
\hline $\begin{array}{l}\text { Total suspended carbon } \\
\text { CO }, \text { total suspended organic } \\
\text { carbon (TOC) }\end{array}$ & $5 \mathrm{~s}^{-1}$ \\
\hline $\begin{array}{l}\text { Aerosol mass spectrometer } \\
\text { (Aerodyne Research Inc.) }\end{array}$ & Particle composition & $1 \mathrm{~min}^{-1}$ \\
\hline $\begin{array}{l}\text { Scanning mobility particle } \\
\text { sizer (TSI) }\end{array}$ & Particle size distribution & $0.4 \mathrm{~min}^{-1}$ \\
\hline $\begin{array}{l}\text { Ozone monitor }(2 \mathrm{~B} \\
\text { Technologies) }\end{array}$ & $\mathrm{O}_{3}$ & $0.1 \mathrm{~s}^{-1}$ \\
\hline $\begin{array}{l}\text { NO-NO} \\
\text { (Thermo Fisher) }\end{array}$ analyzer & ${\mathrm{NO}, \mathrm{NO}_{2}}$ & $0.1 \mathrm{~s}^{-1}$ \\
\hline
\end{tabular}

${ }^{a}$ All gas-phase data in the figures are 1-min average.

Table S3: Air cleaners tested and VOC single-pass efficiency $\left(\eta_{\mathrm{VOC}}\right)^{\mathrm{a}}$ determined for additions of toluene or limonene.

\begin{tabular}{|c|c|c|c|c|c|}
\hline $\begin{array}{l}\text { Cleaner } \\
\text { No. }\end{array}$ & $\begin{array}{l}\text { Operative } \\
\text { technologies (as } \\
\text { provided by the } \\
\text { manufacturer) }\end{array}$ & $\begin{array}{l}\text { Operating } \\
\text { conditions }\end{array}$ & $\begin{array}{c}\text { Chamber } \\
\text { RH }\end{array}$ & $\eta_{\text {toluene }}$ & $\eta_{\text {limonene }}$ \\
\hline \multirow{4}{*}{$\mathrm{P} 1$} & \multirow{4}{*}{$\begin{array}{c}\mathrm{UV}-\mathrm{C}+\mathrm{TiO}_{2}, \\
\text { HEPA, activated } \\
\text { charcoal }\end{array}$} & $\begin{array}{c}\text { P1a: All } \\
\text { technologies }\end{array}$ & $37 \%$ & $0.02(0.02-0.02)$ & $0.02(0.02-0.02)$ \\
\hline & & $\begin{array}{l}\text { P1b: Charcoal, } \\
\text { HEPA }\end{array}$ & $36 \%$ & $0.02(0.02-0.02)$ & $0.02(0.02-0.02)$ \\
\hline & & P1c: UV+TiO 2 & $37 \%$ & $0.00(0.00-0.00)$ & $0.00(0.00-0.00)$ \\
\hline & & P1d: $\mathrm{UV}+\mathrm{TiO}_{2}$ & $8 \%-9 \%$ & $0.00(0.00-0.00)$ & $0.00(0.00-0.00)$ \\
\hline $\mathrm{P} 2$ & $\begin{array}{l}\text { UV-C, negative } \\
\text { ions, carbon } \\
\text { filtration } \\
\end{array}$ & $\begin{array}{c}\text { P2a: All } \\
\text { technologies }\end{array}$ & $35 \%$ & $0.05(0.02-0.08)$ & \\
\hline \multirow{2}{*}{ P3 } & \multirow{2}{*}{$\begin{array}{c}\text { Plasma } \\
\text { technology, } \\
\text { prefilter, HEPA, } \\
\text { carbon filter }\end{array}$} & $\begin{array}{c}\text { P3a: All } \\
\text { technologies }\end{array}$ & $36 \%-37 \%$ & $0.00(0.00-0.00)$ & \\
\hline & & $\begin{array}{l}\text { P3b: Plasma unit } \\
\text { + prefilter }\end{array}$ & $37 \%-38 \%$ & $0.00(0.00-0.00)$ & \\
\hline P4 & $\begin{array}{c}\text { Photo } \\
\text { electrochemical }\end{array}$ & $\begin{array}{c}\text { P4a: All } \\
\text { technologies }\end{array}$ & $35 \%-36 \%$ & $0.32(0.32-0.32)$ & $0.44(0.44-0.44)$ \\
\hline
\end{tabular}




\begin{tabular}{|c|c|c|c|c|c|}
\hline oxidation filter & $\begin{array}{c}\text { P4b: All } \\
\text { technologies }\end{array}$ & $8 \%-9 \%$ & $0.34(0.34-0.34)$ & $0.48(0.48-0.49)$ \\
\cline { 3 - 6 } & $\begin{array}{c}\text { P4c: UV lights } \\
\text { covered }\end{array}$ & $9 \%$ & $0.29(0.29-0.29)$ & $0.31(0.31-0.31)$ \\
\cline { 2 - 5 } & $\begin{array}{c}\text { P4d: All } \\
\text { technologies }\end{array}$ & $75 \%$ & $0.17(0.17-0.17)$ & $0.25(0.25-0.25)$ \\
\hline
\end{tabular}

${ }^{\mathrm{a}} \eta_{\mathrm{VOC}}=\operatorname{CADR}_{\mathrm{VOC}}\left(\mathrm{m}^{3} \mathrm{~h}^{-1}\right) / \mathrm{Q}\left(\mathrm{m}^{3} \mathrm{~h}^{-1}\right)$.

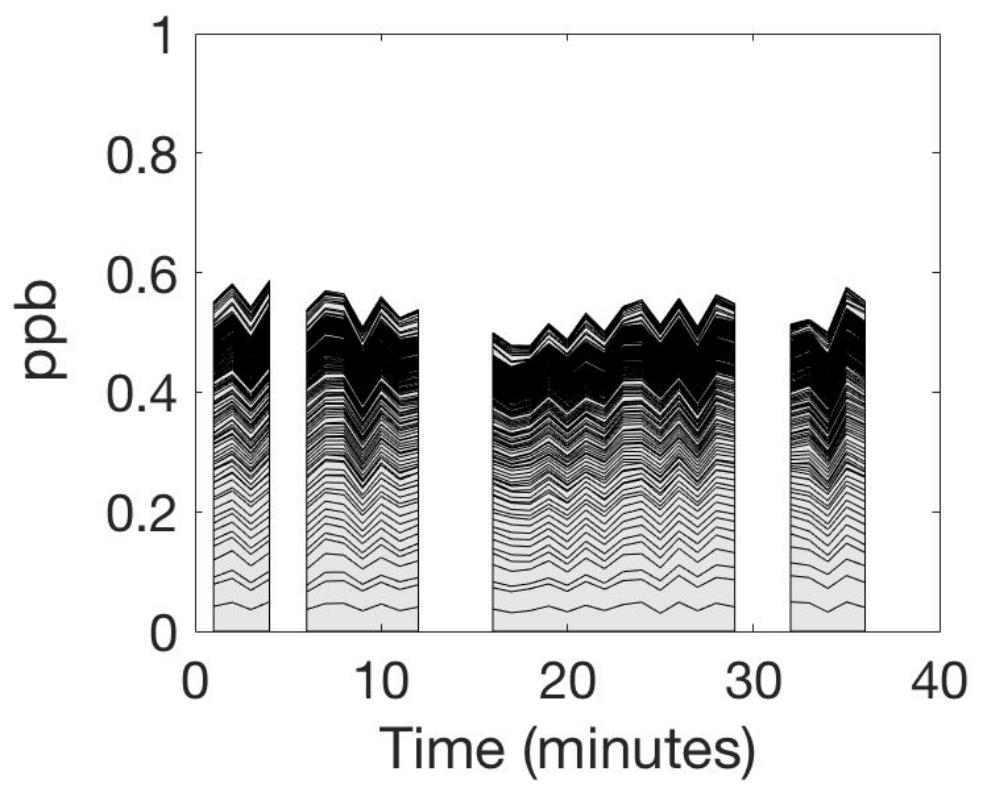

Figure S2: Chamber background measured by the vocus-PTR. Major ions detected include $\mathrm{C}_{2} \mathrm{H}_{5} \mathrm{O}_{2}^{+}$(acetic acid), $\mathrm{C}_{2} \mathrm{H}_{6} \mathrm{O}_{3}^{+}$(potentially the water cluster of acetic acid) and $\mathrm{C}_{3} \mathrm{H}_{7} \mathrm{O}^{+}$ (acetone). There was no detectable formaldehyde. 
(a) Toluene

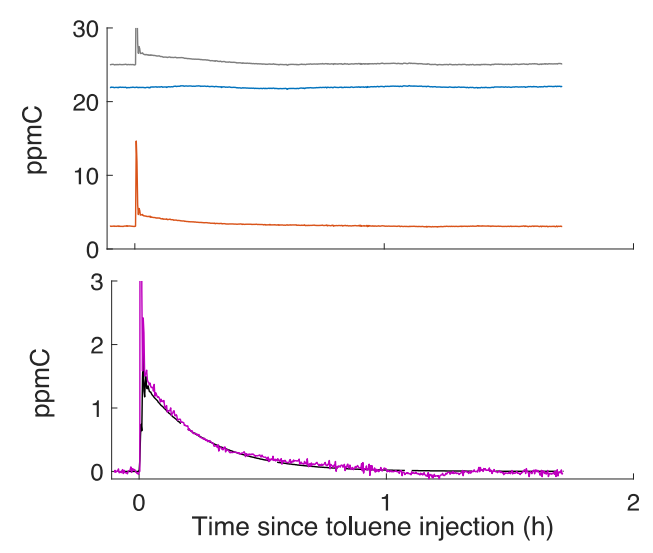

(b) Limonene

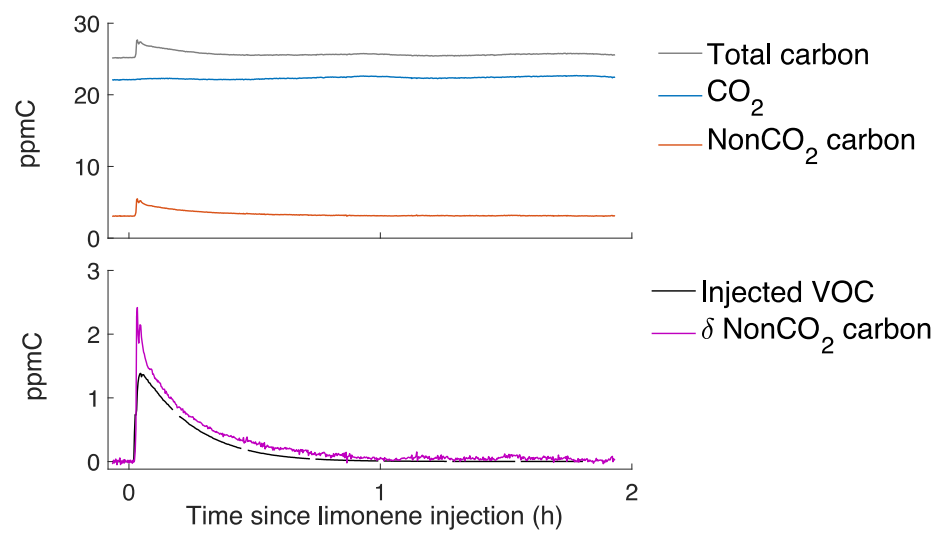

Figure S3: Total carbon, $\mathrm{CO}_{2}$, and total nonCO $\mathrm{C}_{2}$ carbon measured by the TOC measurement during the removal of toluene (a) and limonene (b) using P4. The concentration of the injected VOC is measured by the vocus-PTR.

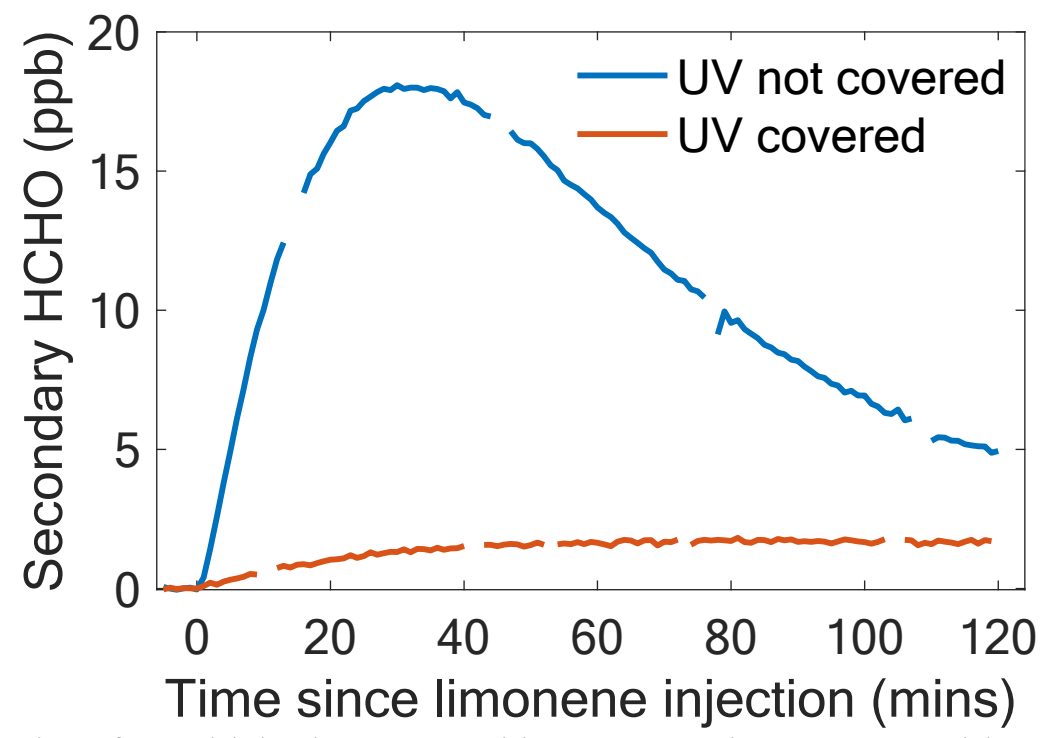

Figure S4: Secondary formaldehyde measured in two experiments, one with UV lights in P4 not covered (blue) and one with UV lights covered (orange), under 8-9\% RH. Here formaldehyde is used as an indicator of how much of the photochemistry in the filter was inhibited. The slight increase of formaldehyde in orange (with concentration 10x less the in blue) could be due to some leak of UV from the cover, but overall the photochemistry was largely inhibited. 


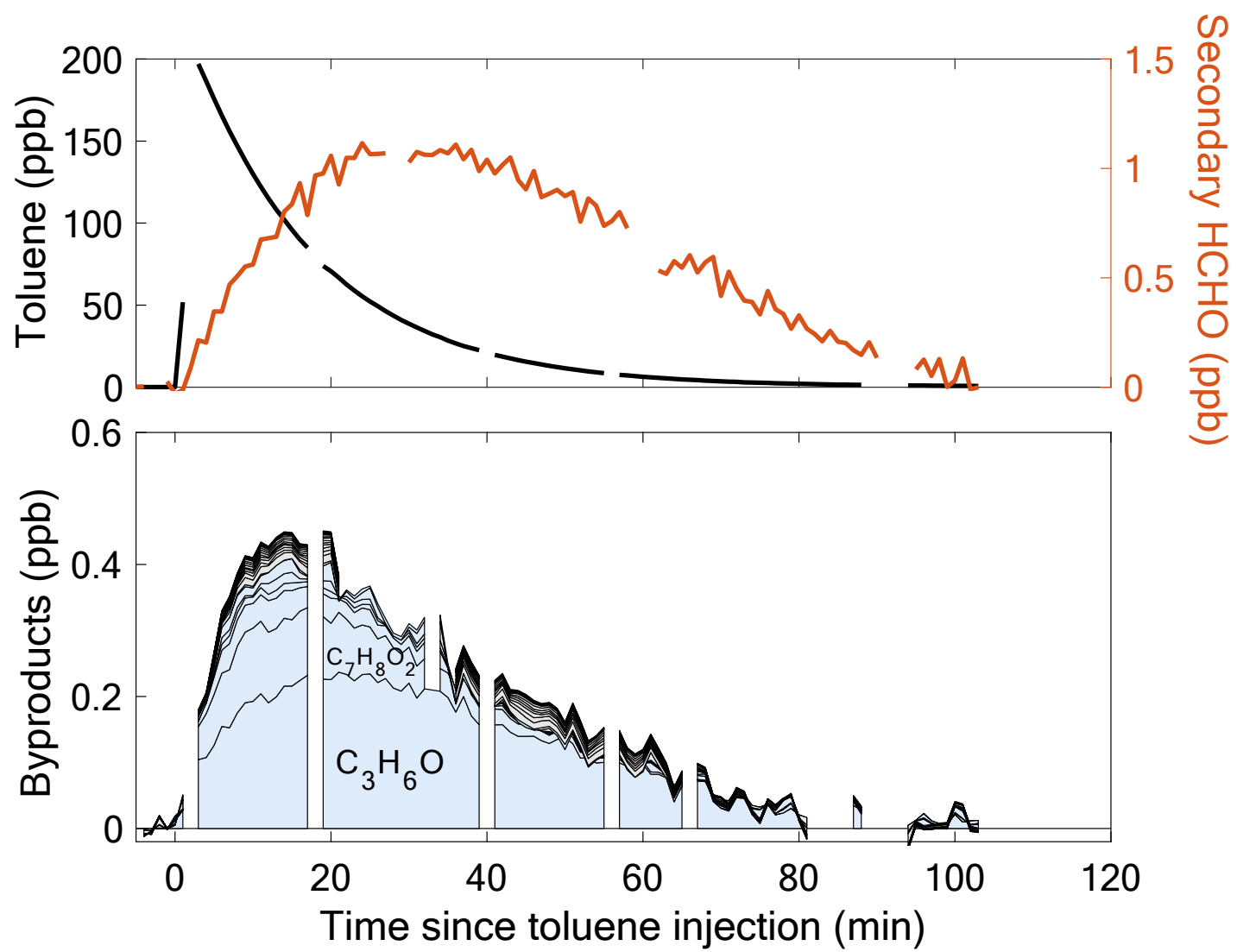

Figure S5: Removal of toluene by P4 forming byproducts including formaldehyde, acetone and other VOCs measured by the vocus-PTR (blue) and the $\mathrm{NH}_{4}-\mathrm{CIMS}$. Similar to Figure 3(b), byproduct concentrations were determined by measuring the difference between an experiment in which the full filter was used and an experiment in which the UV lights inside the cleaner were covered, both under $8-9 \% \mathrm{RH}$. The stable $\mathrm{CO}_{2}$ concentratin in the chamber indicates that negligible amount of toluene is converted to $\mathrm{CO}_{2}$. 


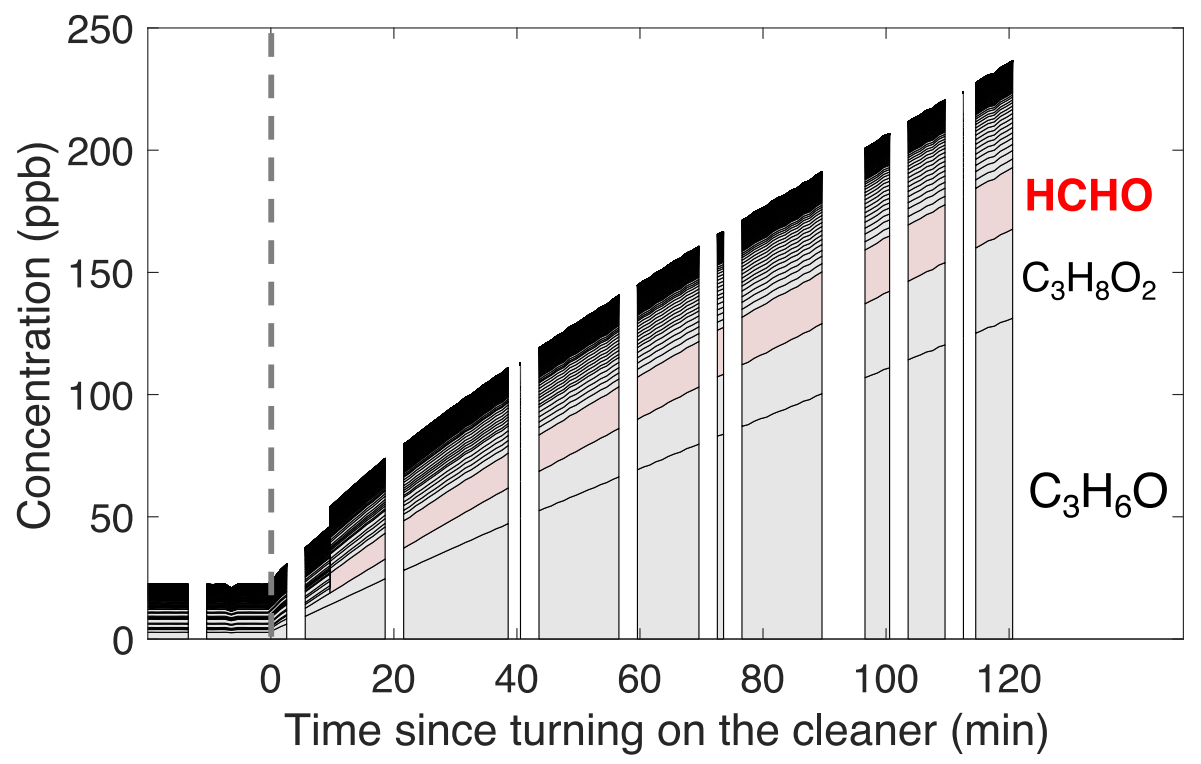

Figure S6: Direct emissions from P4 under 75\% RH measured by Vocus-PTR (grey) and FILIF ( $\mathrm{HCHO}$, light red). Species measured by the $\mathrm{NH}_{4}$-CIMS made up a small fraction of the total concentration and are not shown here. Concentrations have been corrected for chamber dilution. The cleaner was turned on at $\mathrm{t}=0$ (grey dashed lines)

\section{References:}

(1) Krechmer, E. J.; Lopez-hil, F.; Koss, A.; Hutterli, M.; Stoermer, C.; Deming, B.; Kimmel, J.; Warneke, C.; Holzinger, R.; Jayne, J.; Worsnop, D.; Fuhrer, K.; Gonin, M; de Gouw, J. Evaluation of a New Reagent-Ion Source and Focusing Ion-Molecule Reactor for Use in Proton-Transfer-Reaction Mass Spectrometry. Anal. Chem. 2018, 90, 12011-12018. https://doi.org/10.1021/acs.analchem.8b02641.

(2) Cappellin, L.; Karl, T.; Probst, M.; Ismailova, O.; Winkler, P. M.; Soukoulis, C.; Aprea, E.; Märk, T. D.; Gasperi, F.; Biasioli, F. On Quantitative Determination of Volatile Organic Compound Concentrations Using Proton Transfer Reaction Time-of-Flight Mass Spectrometry. Environ. Sci. Technol. 2012, 46 (4), 2283-2290. https://doi.org/10.1021/es203985t.

(3) Zaytsev, A.; Breitenlechner, M.; Koss, A. R.; Lim, C. Y.; Rowe, J. C.; Kroll, J. H.; Keutsch, F. N. Using Collision-Induced Dissociation to Constrain Sensitivity of Ammonia Chemical Ionization Mass Spectrometry $\left(\mathrm{NH}_{4}{ }^{+} \mathrm{CIMS}\right)$ to Oxygenated Volatile Organic Compounds. Atmos. Meas. Tech. 2019, 12 (3), 1861-1870. https://doi.org/10.5194/amt12-1861-2019.

(4) Hansel, A.; Scholz, W.; Mentler, B.; Fischer, L.; Berndt, T. Detection of $\mathrm{RO}_{2}$ Radicals and Other Products from Cyclohexene Ozonolysis with $\mathrm{NH}_{4}{ }^{+}$and Acetate Chemical Ionization Mass Spectrometry. Atmos. Environ. 2018, 186 (November 2017), 248-255. https://doi.org/10.1016/j.atmosenv.2018.04.023.

(5) Breitenlechner, M.; Fischer, L.; Hainer, M.; Heinritzi, M.; Curtius, J.; Hansel, A. PTR3: An Instrument for Studying the Lifecycle of Reactive Organic Carbon in the Atmosphere. Anal. Chem. 2017, 89 (11), 5824-5831. https://doi.org/10.1021/acs.analchem.6b05110.

(6) Hottle, J. R.; Huisman, A. J.; DiGangi, J. P.; Kammrath, A.; Galloway, M. M.; Coens, K. 
L.; Keutsch, F. N. A Laser Induced Fluorescence-Based Instrument for in-Situ Measurements of Atmospheric Formaldehyde. Environ. Sci. Technol. 2009, 43 (3), 790795. https://doi.org/10.1021/es801621f.

(7) DiGangi, J. P.; Boyle, E. S.; Karl, T.; Harley, P.; Turnipseed, A.; Kim, S.; Cantrell, C.; Maudlin, R. L.; Zheng, W.; Flocke, F.; Hall, S. R.; Ullmann, K.; Paul, J. B.; Wolfe, G. M.; Desai; A. R.; Kajii. Y.; Guenther, A.; Keutsch, F. N. First Direct Measurements of Formaldehyde Flux via Eddy Covariance: Implications for Missing in-Canopy Formaldehyde Sources. Atmos. Chem. Phys. 2011, 11 (20), 10565-10578. https://doi.org/10.5194/acp-11-10565-2011.

(8) Cazorla, M.; Wolfe, G. M.; Bailey, S. A.; Swanson, A. K.; Arkinson, H. L.; Hanisco, T. F. A New Airborne Laser-Induced Fluorescence Instrument for in Situ Detection of Formaldehyde throughout the Troposphere and Lower Stratosphere. Atmos. Meas. Tech. 2015, 8 (2), 541-552. https://doi.org/10.5194/amt-8-541-2015.

(9) Shutter, J.; Allen, N.; Hanisco, T.; Wolfe, G.; St. Clair, J.; Keutsch, F. A New LaserBased and Ultra-Portable Gas Sensor for Indoor and Outdoor Formaldehyde (HCHO) Monitoring. Atmos. Meas. Tech. 2019, 12, 6079-6089. https://doi.org/10.5194/amt-2018443.

(10) Veres, P.; Gilman, J. B.; Roberts, J. M.; Kuster, W. C.; Warneke, C.; Burling, I. R.; De Gouw, J. Development and Validation of a Portable Gas Phase Standard Generation and Calibration System for Volatile Organic Compounds. Atmos. Meas. Tech. 2010, 3 (3), 683-691. https://doi.org/10.5194/amt-3-683-2010.

(11) Chen, W.; Zhang, J. S.; Zhang, Z. Performance of Air Cleaners for Removing Multiple Volatile Organic Compounds in Indoor Air. ASHRAE Trans. 2005, 111 PART 1 (January 2005), 1101-1114. 